\title{
Persepsi anak terhadap dokter gigi pada Rumah Sakit Gigi Mulut Halimah Dg. Sikati di Makassar (Children's perception of their dentist at Halimah Dg.Sikati Dental Hospital in Makassar)
}

\author{
Ayub Irmadani Anwar \\ Bagian Ilmu Kesehatan Gigi Masyarakat \\ Fakultas Kedokteran Gigi Universitas Hasanuddin \\ Makassar, Indonesia
}

\begin{abstract}
Management of child behavior begins when the children enters the dental environment and continues until they leave it. Fear of dentist and dental treatment have been considered a major hindrance to provide a quality dental services. Establish a friendly relationship with children is important for dentist to combat patient's fears and to deliver effective and efficient treatment. The aim of this study was to assess children's feelings and attitudes toward their dentist in Halimah Dg. Sikati Dental Hospital. A questionnaire designed to evaluate children's attitudes and preferences toward dentists was completed by 45 children (29 females, 19 males) who attended the hospital. It showed $80 \%$ of the subject reported that they had been to the dentist before; $84.4 \%$ report liked their visit, and $8.9 \%$ were afraid. A 93,3\% of the children preferred their dentist to wear a white coat, while $80 \%$ preferred them to wear a mask, $82.2 \%$ preferred to be treated by a female dentist, while 77,8\% reported that their sibling had a pleasant perception. $80 \%$ of the children preferred that their dentist wear the formal attire. Fear of local anesthesia and tooth extraction were the most common reasons cited for not liking dental treatment. It was concluded that children have strong perceptions and preferences regarding their dentists.
\end{abstract}

Keywords: dental care, perception, dentist

\begin{abstract}
ABSTRAK
Penatalaksanaan prilaku anak dimulai saat anak masuk dan berlanjut hingga anak meninggalkan lingkungan dokter gigi. Ketakutan terhadap dokter gigi dan perawatan gigi dianggap sebagai hambatan utama untuk memberikan perawatan gigi yang berkualitas. Membangun hubungan yang bersahabat dengan pasien, utamanya anak-anak, merupakan hal yang penting bagi dokter gigi untuk melawan ketakutan pasien dan memberikan perawatan yang efektif dan efisien. Penelitian ini dimaksudkan untuk mengetahui perasaan dan sikap anak terhadap dokter gigi di RSGM Halimah Dg. Sikati. Sebuah kuesioner dirancang untuk mengevaluasi sikap dan preferensi anak terhadap dokter gigi pada subjek sejumlah 45 anak (29 perempuan, 16 laki-laki). Hasilnya menunjukkan bahwa $80 \%$ anak pernah berkunjung ke dokter gigi sebelumnya. Jika 84,4\% menyukai kunjungan mereka, dan 8,9\% takut, sekitar 77,8\% subjek melaporkan bahwa saudaranya menyukai kunjungan mereka. Sejumlah 93,3\% menyukai dokter gigi yang memakai jas putih, 80\% lebih suka dokter gigi yang mengenakan masker, $80 \%$ subjek penelitian menyukai dokter gigi mereka mengenakan pakaian formal. Sedangkan $82,2 \%$ subjek lebih suka dirawat oleh dokter gigi perempuan. Ketakutan terhadap anestesi lokal dan ekstraksi gigi adalah alasan paling umum yang menyebabkan anak-anak tidak menyukai perawatan gigi. Disimpulkan bahwa pasien anak yang berobat pada RSGM Halimah Dg. Sikati memiliki persepsi yang kuat dan preferensi tentang dokter gigi.
\end{abstract}

Kata kunci: perawatan gigi, persepsi, dokter gigi

Koresponden: Ayub Irmadani Anwar, E-mail:ayubanwar_mks@yahoo.com

\section{PENDAHULUAN}

Suatu kemampuan untuk mengarahkan anak membentuk pengalaman yang baik tentang dokter gigi merupakan dasar dalam praktik kedokteran gigi anak. Manajemen prilaku anak dimulai saat pertama kali anak tersebut masuk ke lingkungan dokter gigi dan berlanjut sampai anak meninggalkan tempat itu. ${ }^{1,2}$

Pasien hanya akan ke dokter gigi ketika mereka mengalami sakit gigi yang tak tertahankan. Ketakutan terhadap dokter gigi dan perawatan gigi dianggap sebagai hambatan utama untuk perawatan gigi yang berkualitas. Rasa takut terhadap perawatan gigi dapat dijumpai pada anak di berbagai unit layanan kesehatan gigi, misalnya dipraktik dokter gigi, rumah sakit atau di puskesmas. Survei menunjukkan bahwa antara 5$6 \%$ dari populasi dan $16 \%$ anak usia sekolah yang memiliki ketakutan terhadap dokter gigi. ${ }^{3,4}$

Perawatan pada pasien anak berbeda dengan perawatan pasien dewasa. Hal ini penting bagi dokter gigi untuk membangun hubungan yang bersahabat dengan pasien, terutama pasien anak, dalam rangka memerangi ketakutan pasien dan untuk memberikan perawatan yangefektifdan efisien. Adanya hubungan yang kuat pada kunjungan pertama anak membantu menciptakan suasana nyaman sehingga mereka tidak merasa terancam. Anak sering membuat penilaian tentang dokter gigi mereka berdasarkan penampilan dokter gigi dan sering merekam serta menganalisis 
setiap kata, gerakan, dan isyarat dokter gigi mereka selama perawatan. ${ }^{1,4}$

Sebuah hubungan yang bersahabat dengandokter gigi membantu pasien dalam mengatasi rangsangan identifikasi khusus, sepertijarum suntik anastesi dan penglihatan, suara, dan sensasi dari handpiece dan buryang telah terbukti dapat memancing kecemasan. Miller menekankan perlunya mengurangi sebanyak mungkin kecemasan pasien dan ketakutan terhadap kedokteran gigi, karena ketakutan bermula di masa kecil, sehingga tepat memilih anak-anak sebagai target penelitian ini. Anak yang memiliki interaksi positif dengan dokter gigi mereka, tidak mungkin takut terhadap dokter gigi dan akan mengurangi kecemasan selama bersama dengan dokter gigi. Mengingat pentingnya kesehatan gigi, dokter gigi perlu menyadari persepsi pasien, preferensi, dan ketakutan untuk memenuhi kebutuhan pasien dengan cara menyediakan perawatan yang berkualitas yang menghibur dan mengurangi kecemasan. ${ }^{4}$

Penelitian ini dimaksudkan untuk mengetahui persepsi anak terhadap dokter gigi di RSGM Halimah Dg. Sikati Makassar agar diperoleh informasi bagi dokter gigi untuk melakukan praktikyang lebih baik untuk memenuhi preferensi dan kebutuhan pasien.

\section{BAHAN DAN METODE}

Penelitian observasi deskriptif dengan desain cross sectional study dilakukan di RSGM Halimah Dg. Sikati di Makassar. Sampel penelitian berasal dari seluruh anak yang mengunjungi Klinik Bagian Ilmu Kedokteran Gigi Anak (IKGA) RSGM pada tanggal 9-13 Juli2012. Kriteria inklusi sampel adalah anak yang bersedia mengisi kuesioner penelitian dan telah mempunyai kemampuan membaca, menulis, dan memahami isi kuesioner. Sedangkan kriteria eksklusi sampel adalah anak-anak yang tidak mengisi seluruh pertanyaan pada dalam lembar kuesioner.
Pengolahan data dilakukan dengan program SPSS versi 16.

\section{HASIL}

Dari penelitian ini, diperoleh subjek penelitian sebanyak 45 pasien anak dengan umur 7-12 tahun yang komposisinya untuk anak laki-laki sebesar $35,6 \%$ dan anak perempuan sebesar $64,4 \%$ (Tabel 1).

Tabel 1 Gambaran umum karakteristik subjek penelitian

\begin{tabular}{lcc}
\hline Karakteristik Responden & $\begin{array}{c}\text { Frekuensi } \\
\text { (n) }\end{array}$ & $\begin{array}{c}\text { Persentase } \\
(\%)\end{array}$ \\
\hline Jenis Kelamin & & \\
$\quad$ Laki-laki & 16 & 35,6 \\
Perempuan & 29 & 64,4 \\
Umur & & \\
7 tahun & 3 & 6,7 \\
8 tahun & 6 & 13,3 \\
9 tahun & 16 & 35,6 \\
10 tahun & 12 & 26,6 \\
11 tahun & 5 & 11,1 \\
12 tahun & 3 & 6,7 \\
\hline
\end{tabular}

Tabel 2 mengenai sebaran tanggapan subjek penelitian tentang pengalaman berkunjung ke dokter gigi, $80 \%$ anak sudah pernah mengunjungi dokter gigi. Mengenai perasaan saat mengunjungi dokter gigi, 84,4\% menyukai kunjungan ke dokter gigi dan tidak ada yang merasa takut. Sedangkan mengenai perasaaan saudara atau keluarga ketika mengunjungi dokter gigi, 77,8\% dari subjekpenelitian melaporkan bahwa saudaranya menyukai kunjungan mereka ke dokter gigi. Meskipun demikian, selebihnya tidak suka, takut, dan tidak tahu apa yang dirasakan.

Sebanyak $82,2 \%$ subjek penelitian lebih suka dirawat oleh doktergigi perempuan, 93,3\% menyukai dokter gigi yang mengenakan jas putih daripada jas berwarna (tabel 3). Selain itu, anak lebih suka dokter gigi yang memakai beberapa peralatan pelindung.

Tabel 2 Tanggapan anak tentang kunjungan ke dokter gigi

\begin{tabular}{lcc}
\multicolumn{1}{c}{ Pertanyaan } & Frekuensi (n) & Persentase (\%) \\
\hline Apakah kamu pernah ke dokter gigi sebelumnya? & 36 & 80,0 \\
Ya & 9 & 20,0 \\
Tidak & & \\
Bagaimana perasaan anda selama menjalani perawatan gigi? & 38 & 84,4 \\
Saya merasa senang saat perawatan gigi dilakukan & 0 & 0,0 \\
Saya tidak suka dengan perawatan gigi & 4 & 8,9 \\
Saya Takut & 3 & 6,7 \\
Saya tidak tahu apa yang saya rasakan & & \\
Bagaimana perasaan saudara/keluarga anda ketika mereka & & \\
mengunjungi dokter gigi? & 35 & 77,8 \\
Mereka senang mengunjungi dokter gigi & 3 & 6,7 \\
Mereka tidak suka dengan perawatan gigi & 5 & 11,1 \\
Mereka merasa takut & 2 & 4,4 \\
Mereka tidak tahu apa yang mereka rasakan & & \\
\hline
\end{tabular}


Tabel 3 Persepsi anak terhadap dokter gigi

\begin{tabular}{lcc}
\hline \multicolumn{1}{c}{ Pertanyaan Persepsi } & Frekuensi (n) & Persentase (\%) \\
\hline Anda lebih senang dirawat oleh dokter gigi laki-laki atau perempuan? & & 17,8 \\
$\quad$ Dokter gigi laki-laki & 8 & 82,2 \\
$\quad$ Dokter gigi perempuan & 37 & 93,3 \\
Anda lebih suka dokter gigi yang & 42 & 6,7 \\
$\quad$ Menggunakan jas dokter putih & 3 & 80,0 \\
$\quad$ Menggunakan jas dokter berwarna & & 2,3 \\
Anda lebih senang dokter yang & 36 & 13,3 \\
$\quad$ Menggunakan masker & 1 & 4,4 \\
$\quad$ Menggunakan kaca mata pelindung & 6 & 80,0 \\
$\quad$ Menggunakan masker dan kaca mata pelindung & 2 & 20,0 \\
$\quad$ Tidak menggunakan masker dan kaca mata pelindung & & 36 \\
Anda lebih suka dokter gigi yang & 9 & \\
Menggunakan kemeja dan berpakaian rapi & & \\
Menggunakan kaos/berpakaian santai & & \\
\hline
\end{tabular}

Tabel 4 Faktor penyebab ketakutan

\begin{tabular}{lcc}
\hline Penyebab ketakutan anak terhadap dokter gigi & Frekuensi (n) & Persentase (\%) \\
\hline Injeksi & 31 & 68,9 \\
Pencabutan gigi & 7 & 15,5 \\
penambalan gigi & 4 & 8,9 \\
Instrumen gigi & 3 & 6,7 \\
\hline
\end{tabular}

Ketika ditunjukkan gambar dokter gigi mengenakan kacamata pelindung, masker dan gambar dokter gigi memakaimaskerdankacamata pelindung, $80 \%$ subjek penelitianmemilih gambar doktergigi yang memakai masker; $80 \%$ subjek penelitian menyukai dokter gigi yang mengenakan kemeja dan berpakaian rapi dari pada yang mengenakan pakaian santai.

Sedangkan pada tabel 4 mengenai faktor penyebab ketakutan anak, ketakutan ini terkait dengan injeksi $(68,9 \%)$, pencabutan gigi $(15,5 \%)$, penambalan gigi $(8,9 \%)$, dan instrumen gigi $(6,7 \%)$.

\section{PEMBAHASAN}

Dari hasil penelitian ini terungkap bahwa anak memiliki persepsi yang kuat dan preferensi tentang kunjungan ke dokter gigi. Mayoritas $(84,4 \%)$ anak dalam penelitian ini melaporkan bahwa mereka menyukai kunjungan mereka ke dokter gigi. Hasil ini konsisten dengan hasil penelitian lain yang telah meneliti perilaku anak terhadap perawatan gigi. ${ }^{4,5}$ Namun, doktergigi harus peduli dengan fakta bahwa masih ada $8,9 \%$ subjekpenelitian yang takut terhadap dokter gigi.

Tujuan mengidentifikasi sikap anak terhadap dokter gigi mereka adalah untuk memberikan efek berupa perubahan positifatau penyesuaian yang akan membuat anak lebih nyaman di klinik dokter gigi dan meningkatkan kualitas kunjungan ke dokter gigi. Anak-anak dalam penelitian ini lebih memilih dirawatoleh doktergigi berjenis kelamin perempuan. Hal ini menunjukkanhasil yang berbeda dengan hasil penelitian lain yang telah meneliti sikap anak terhadap doktergigi yang menunjukkan bahwa anak-anak lebih suka dirawat oleh dokter gigi dari gender yang sama. ${ }^{4}$

Penampilan fisik terbukti menjadi faktor yang dipertimbangkan untuk memilih seseorang dokter keluarga dan berperan penting dalam pengembangan hubungan dokter-pasien. Hasil dari penelitian ini menunjukkan bahwa anak lebih memilih dokter gigi mereka untuk memakai pakaian formal dengan jas putihdi klinik gigi. Temuan ini sesuai penelitian yang dilakukan oleh McCarthy et al yang bertentangan dengan pemahaman yang populer, yang menyatakan bahwa anak-anak tidak takut pada dokteryangberjas putih dan melihat dokter berpakaian formal sebagai sebagai orang yang lebih kompeten dan peduli. Hal inisesuai denganhasil penelitian lainnya,yaitu pasien dewasa mengharapkan dan menyukai dokter lakilaki yang mengenakan setelan formal dan dasi. ${ }^{6-8}$

Anak-anakmungkin lebihmenyukai jas putih karena dapat melihatnya sebagai simbol penyembuhan. Hal ini sesuai dengan McKinstry dan Wang ${ }^{9}$ pada sikap pasien terhadap cara berpakaian para dokter. Sebagian besar pasien (64\%) berpikir bahwa cara berpakaiandokter merupakan hal yangpenting karena banyak pasienyangmerasa bahwa mereka akan lebih percaya dokter yang mengenakan jas putih. Namun, temuan ini berbeda dari hasil penelitian lain yang menemukan bahwapara pasien kurang menyukai jas putih. $^{10,11}$

Pentingnya peraturan mengenai pakaian yang tepat dan menggunakan pakaian pelindung untuk 
melindungi pasien dan penyedia perawatan kesehatan sehingga terhindar dari penularan penyakit menular di klinik gigi. Hal ini juga penting untuk meneliti bagaimana pasien memandang pakaian pelindung tertentu danuntuk mengevaluasi apakah penggunaan pakaian tertentu meningkatkan atau menurunkan kepuasan pasien dengan perawatan. Penelitian ini menunjukkan bahwa sebagian besar anak-anak lebih menyukai dokter gigi yang menggunakan masker selama perawatan gigi. Hal inisama dengan data yang dilaporkan Shulman dan Brehm, yaitu 70\% subjek lebihmenyukai doktergigi yang mengenakan masker selama perawatan gigi. Anak mungkin terintimidasi oleh perangkat pelindung, seperti kacamata serta masker, dan mungkin tidak menyadari maksud pelindung tersebut digunakan. Dokter gigi dapat menenangkan kecemasan pasien anak-anak, dengan menjelaskan tujuan perangkatpelindung tersebut. ${ }^{10,12}$

Untuk membuat perubahan berdampak positif dan penyesuaian yang akan membuat kunjungan ke dokter gigi lebih menarik, adalah penting untuk memahami apa yang anak lihat sebagai aspek yang tidak menyenangkan tentang kunjungan ke dokter gigi.Anak-anakmenyimpulkan injeksi dan ekstraksi gigi sebagai hal yang paling menakutkan dan simbol rasa takut dari dunia kedokteran gigi. Temuan dari penelitian ini serupa dengan hasil penelitianlain yang menekankan kebutuhan untuk hanya menggunakan instrumen yang diperlukan selama perawatan dan penggunaantekniktell-show-do selama pengobatan. ${ }^{4}$

Faktortertentu lainnyayang dapat berkontribusi terhadap ketakutan anak mengunjungi dokter gigi, seperti saudara kandung yang menceritakan hal yang menakutkan tentang kunjungan mereka sebelumnya ke klinik gigi. Adanya $6,7 \%$ pasien yang melaporkan bahwa saudaranya tidak suka kunjungan mereka ke doktergigidan $11,1 \%$ melaporkan bahwa saudaranya takut pada dokter gigi. Hasil tersebut menekankan pentingnya memastikan bahwa anak-anak merasa nyaman selama kunjungan mereka kedoktergigidan memiliki pengalaman positif. Anak yang memiliki kesan negatif dengan dokter gigi cenderung akan menyebarkannya kepada anak lain. Kesan negatif ini sulit diatasi, terutama pada anak yang baru pertama kali membentuk persepsi terhadap dokter gigi.

Hasil penelitian ini memberikan wawasan baru tentang persepsi anak-anak terhadap dokter gigi dan perawatan gigi yang harus digunakan oleh dokter gigi untuk memperbaiki praktik. Disimpulkan bahwa anak memiliki preferensi yang kuat mengenai penampilan dokter dan klinik gigi, serta ketakutan diidentifikasi terkait dengan kunjungan ke dokter gigi. Berdasar hal tersebut, dokter gigi hendaknya memperhatikan segala hal yang dapat membuat kualitas kunjungan anak ke dokter gigi meningkat sehingga tercipta perawatan yang optimal pada pasien.

\section{DAFTAR PUSTAKA}

1. McDonald RE, Avery DR, Dean JA. Dentistry for child and adolescent. $8^{\text {th }}$ Ed. Saint Louis: Mosby; 1995.p. 35-49

2. Mathewson RJ, Primosch RE. Fundamentals of pediatric dentistry. $3^{\text {rd }}$ Ed. Carol Stream: Quintessence Books; 1995. p. 7-23

3. Gerschman JA. Hypnoiability and dental phobic disorders. Anesth Prog 1989; 36: 127-39

4. AlSarheed M. Children's perception of their dentists. Eur J Dent 2011; 5: 186-90

5. Corah NL, Gale EN, Illig SJ. The use of relaxation and distraction to reduce psychological stress during dental procedures. J Am Dent Assoc 1979; 98: 390-4

6. Dunn JJ, Lee TH, Percelay JM, Fitz JG. Goldman patient and officer attitudes on physician attire and etiquette. J Am Med Assoc 1987; 257: 65-8

7. McCarthy JJ, McCarthy MC, Eilert RE. Children's and parents' visual perception of physicians. Clin Pediatr 1999; 38: $145-52$

8. Shulman ER, Brehm WT. Dental clinical attire and infection-control procedures. J Am Dent Assoc 2001; 4: 508-16

9. McKinstry B, Wang JX. Putting on the style: What patients think of the way their doctor dresses. Br J Gen Pract $1991 ; 41: 275-8$

10. Gooden BR, Smith MS, Tattersall JN, Stockler MR. Hospitalised patients' view on doctors and white coats. Med J Aust 2001; 175: 219-21

11. Dover S. Glasgow patients' attitude to doctors' dress and appearance. Health Bull 1991; 49: 293-6

12. Gjerdingen DK, Simpson DE, Titus SL. Patients' and physicians' attitude regarding the physicians' professional appearance. Arch Inter Med 1987; 147: 1209-12 